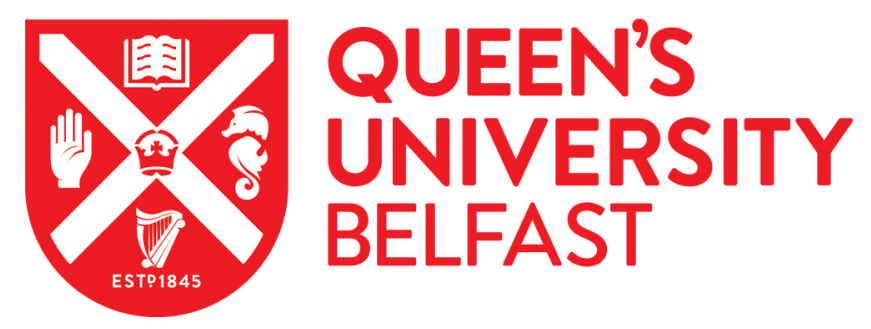

\title{
Understanding Graduate Recruitment, Development and Retention for the Enhancement of Talent Management: Sharpening "the edge" of Graduate Talent
}

McCracken, M., Currie, D., \& Harrison, J. (2016). Understanding Graduate Recruitment, Development and

Retention for the Enhancement of Talent Management: Sharpening "the edge" of Graduate Talent. International Journal of Human Resource Management, 27(22), 2727-2752. https://doi.org/10.1080/09585192.2015.1102159

Published in:

International Journal of Human Resource Management

Document Version:

Peer reviewed version

Queen's University Belfast - Research Portal:

Link to publication record in Queen's University Belfast Research Portal

Publisher rights

(c) 2015 Informa UK Limited, trading as Taylor \& Francis Group

This is an Accepted Manuscript of an article published by Taylor \& Francis in The International Journal of Human Resource Management on 30 Oct 2015, available online: http://www.tandfonline.com/doi/full/10.1080/09585192.2015.1102159

\section{General rights}

Copyright for the publications made accessible via the Queen's University Belfast Research Portal is retained by the author(s) and / or other copyright owners and it is a condition of accessing these publications that users recognise and abide by the legal requirements associated with these rights.

\section{Take down policy}

The Research Portal is Queen's institutional repository that provides access to Queen's research output. Every effort has been made to ensure that content in the Research Portal does not infringe any person's rights, or applicable UK laws. If you discover content in the

Research Portal that you believe breaches copyright or violates any law, please contact openaccess@qub.ac.uk. 
Understanding Graduate Recruitment, Development and Retention for the

Enhancement of Talent Management: Sharpening "the edge" of Graduate Talent

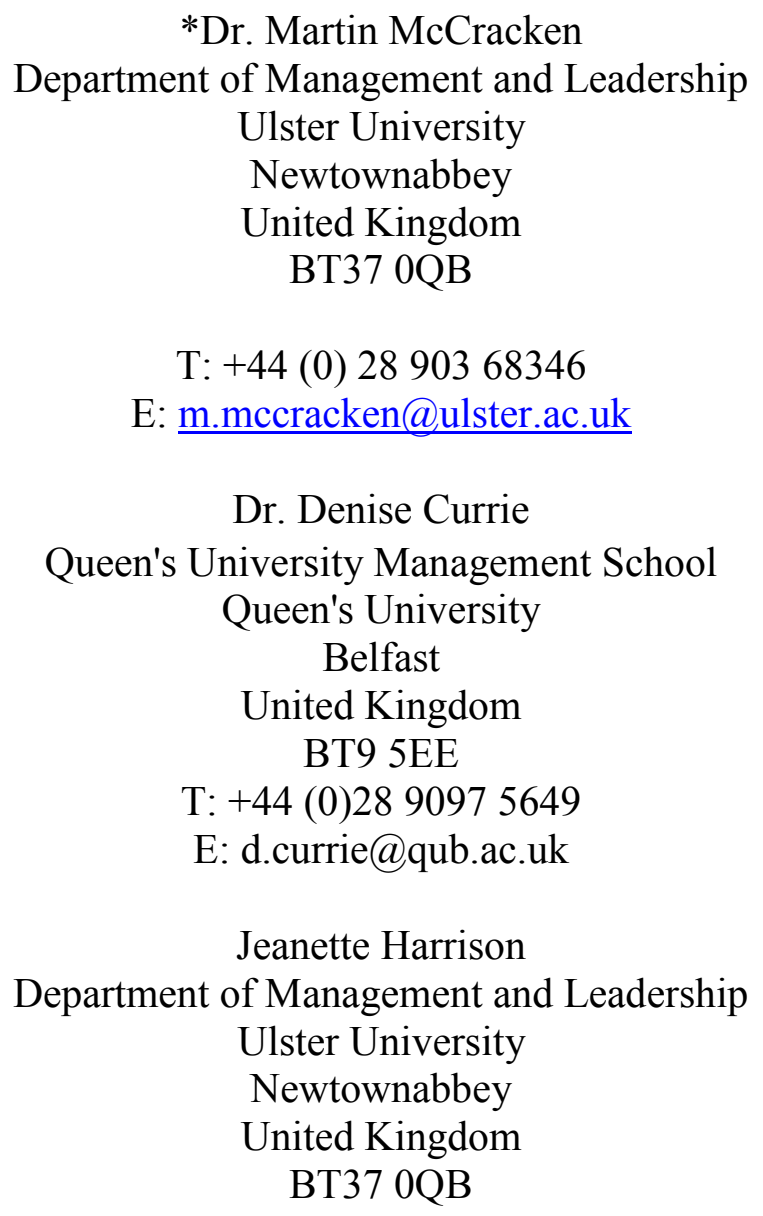

$\mathrm{T}:+44(0) 2890368151$

E: j.harrison@ulster.ac.uk

* Corresponding Author 


\begin{abstract}
Graduates are deemed to be a key source of talent within many organisations and thus recruiting, developing and retaining them is viewed as a logical talent management (TM) strategy. However, there has been little attention paid to university graduates as part of an organisation's TM strategy. Such a specific focus addresses the need for further research into the segmentation of talent pools and the specific challenges different talent pools are likely to create. This research, which utilised a qualitative data collection strategy, examined the experiences and practices of six large UK organisations in relation to graduate TM. Drawing from Gallardo-Gallardo et al.'s (2013) framework for the conceptualisation of talent, the findings from this research indicate and explain why graduate employers are frequently compelled to use the object approach (talent as characteristics of people) due to the unique characteristics that recent graduates possess, even though other studies have found that a subject approach (talent as people and what they do) is preferred by most employers. Ultimately employers conceptualise graduate talent by what they describe as "the edge" which needs to be "sharpened" to fully realise the potential that graduates offer.
\end{abstract}

Key Words: Graduate Recruitment, Graduate development, Talent Management, Graduate Retention, Generation Y. 


\section{Introduction}

Talent Management (TM) has become a critical consideration for organisations in the increasingly uncertain and competitive business environment (Oppong, 2013). It is an activity that is receiving growing attention from practitioners and academics alike and is viewed as an integral aspect of improving organisational performance (Collings and Mellahi, 2009). Nevertheless, it is acknowledged that defining TM and understanding the complexities of how it is implemented in practice has been problematic (see for example, Lewis and Heckman, 2006; Mellahi and Collings, 2010; Oppong, 2013; Vaiman, Scullion and Collings, 2013).

In the quest to clarify TM, scholars have paid increasing attention to a range of issues, such as the conceptualisation of talent (Dries, 2013; Thunnisssen, Boselie and Fruytier, 2013), the degree of inclusivity when managing talent (Gallardo-Gallardo, Driers, and Gonzaléz-Cruz, 2013), the forecasting of talent demand and supply (Capelli, 2008), the alignment between TM and business strategy (Kim and Scullion, 2011; Mellahi and Collings, 2010), and the differences between TM and HRM (Minbaeva and Collings, 2013). TM is acknowledged as an extremely complex issue. It has been defined more generally by Davies and Davies (2010, p. 149) as the "systematic attraction, identification, development, engagement/ retention and deployment of those individuals with high potential who are of particular value to an organisation", whilst Collings and Mellahi (2009, p. 304) define it as being:

"the activities and processes that involve the systematic identification of key positions which differentially contribute to the organisation's sustainable competitive advantage, the development of a talent pool of high potential and high performing incumbents to fill these roles, and the development of a 
differentiated human resource architecture to facilitate filling these positions with competent incumbents and to ensure their continued commitment to the organisation."

The complexity surrounding TM is compounded by the agreement amongst many researchers that a "best fit" or contingency model should be adopted where different strategies are implemented in response to different contexts and workforce characteristics (Boudreau and Ramstad, 2005; Cappelli, 2000; Collings and Mellahi, 2009; Pfeffer, 2001). For example, drawing from the work of Lepak and Snell (1999, 2002) the contingency approach can be implemented through a defined pattern of resource allocation and HR configuration associated with different groups of workers. Stahl, Bjorkman, Farndale, Morris, Paauwe, Stiles, Trevor and Wright (2012) found that workers identified within "talent pools" can be differentiated in terms of senior executives, technical experts and early career high potentials, and that TM practices are designed and implemented to address the different career paths and development strategies of these talent pools in alignment with the overall business strategy. Talent pools are identified which are specifically related to organisational needs thus this approach is very much associated with managerialist and unitarist views where firm performance and the achievement of organisational goals prevail over the interest, motivation and expectations of other stakeholders (Thunnisssen, Coselie and Fruytier, 2013).

The contingency approach can be further complicated when, on the other hand, a more pluralist perspective of the workforce is adopted. For example, conceptual and empirical studies are emerging on how TM should be differentiated for talent pools segmented by generations, particularly as those labeled "Millennials" or "Generation 
Y" (born after 1982) surface in greater numbers. Given the decreasing population of young people in many industrialised countries, competition for attracting and recruiting young talent is fierce amongst employers. Therefore there is growing recognition that to attract Generation Y, TM practices and activities must account for the particular circumstances, interests, values, motivations and aspirations of this group of workers and that organisations should adopt a differentiated TM strategy to address more effectively their psychological contract and expectations (Festing and Schafer, 2014; Shaw and Fairhurst, 2008; Terjesen, Vinnicombe and Freeman, 2007).

Thus, adopting the contingency approach to TM necessitates the recognition that a number of "talent pools" can exist in an organisation and that the TM practices designed to target these different talent pools must consider the wide-ranging goals, expectations and motivations of the organisation, the individual and other stakeholders.

Graduates are one of the most common talent pools and many top-performing organisations view them as a key source of high potential employees (Garavan and Morley, 1997). The importance of recruiting, developing and retaining graduates is therefore regarded as a logical TM strategy that fosters organisational evolution and growth (McDermott, Mangan and O'Connor, 2006). However, graduates are often seen as an enigma because their potential is offset by specific challenges such as poor work readiness and unrealistic expectations about the world of work. Recent graduates also often fall into the Generation Y category which has different characteristics from other workforce generations (Traditionalists, Baby Boomers, and Generation X). This means that those tasked with designing and implementing the right TM strategy for graduates need to understand the specific nature of the graduate talent pool. 
With this in mind, we identified the need for more in depth research designed to offer practical advice to employers to allow them to fully realise the potential of graduate employees, as well as extend our understanding of differentiated TM strategies. The objectives of this research are:

- To identify how "graduate talent" is conceptualised by employers.

- To understand the priorities organisations have in relation to recruiting, developing and retaining graduate talent to achieve organisational objectives.

- To explore the challenges associated with recruiting, developing and retaining graduates (being cognisant of the attributes of Generation Y)

- To uncover innovative or novel practices that employers use to overcome the challenges of managing the graduate talent pool and their associated Generation Y characteristics.

To allow us to fully explore these issues a number of overarching themes have been identified in the literature which are discussed below. In the section that follows, we discuss briefly how talent is conceptualised and the varying approaches to TM strategy and consider issues relating to the recruitment, development and retention of graduates and the challenges associated with addressing graduate TM. After discussing the methods used to collect and analyse the data, the next section discusses the findings of our study in relation to the objectives outlined above. Finally, in the conclusions we suggest how the TM literature could be enriched by taking account of the unique characteristics and associated challenges and opportunities of graduates.

\section{Talent and Talent Management}


TM can be adopted using various approaches which largely depend on how talent is conceptualised by employers. For example, Gallardo-Gallardo et al. (2013) contend that two dimensions are of importance when considering TM. Table 1 sets out the approaches to TM given these dimensions.

---Insert Table 1 about here-----

The first distinction is made between an inclusive (all employees) or an exclusive (select employees) approach. The inclusive approach includes everyone in the organisation and recognises that every employee has his or her own strengths which can add value to the organisation (Buckingham and Vosburgh, 2001). The exclusive approach on the other hand, is based on the notion that those deemed as talent are an "elite subset of the organisation" identified on the basis of some criteria, usually in relation to their unique characteristics or high performance (Gallardo-Gallardo et al. 2013, p.295). The criteria used to identify talent will depend upon whether an object (talent as characteristics of people) or subject (talent as people) approach is adopted

Gallardo-Gallardo (2013, p. 293) describe the object approach as talent conceptualised as being people with "exceptional characteristics" and can be further distinguished in terms of natural ability, mastery, commitment or fit with the organisational context. On the other hand, the subject approach conceptualises talent as people who can make a difference to organisational performance whether through their immediate contribution or in the longer term by demonstrating the highest levels of potential (Tansley, 2007, p.8). To identify such people as talent, it is argued that employers must have a clear idea about the past performance of employees (or potential employees). 
In a study that examined the TM strategies and practices of 33 multinational corporations, Stahl et al. (2012) found that many organisations prefer to differentiate TM by taking an exclusive subject approach in which high performing workers or those with high potential (alternatively classed as "A" players) are subject to a range of more favourable rewards, incentives and developmental opportunities. However although this research study and others (eg. Iles, Preece and Chuai, 2010) suggest that an exclusive subject approach may be favoured; other studies have found that talent is more commonly conceptualised drawing from the object approach. For example, Fleming and Asplund (2008) discuss talent as being aspects of personality or behaviour and interesting frameworks have also been found in the literature on giftedness (Gagné, 2004) and strengths (Biswas-Dierner, Kashdan and Minhas, 2011), whilst Valverde, Scullion and Ryan (2013) described talent in Spanish SMEs as attitude, performance, identification with and loyalty to the company.

Graduates are often described as a cohort of employees with "high potential" but it is unclear what potential means to graduate employers. Gallardo-Gallardo et al. (2013) suggest that in practice the label of "high potential" is often based upon past performance data, however graduates often lack the work experience to demonstrate their performance levels and the experience they do have may be insufficient for employers to judge appropriately. One way to identify the performance potential of graduates at the recruitment stage is through using more sophisticated selection methods such as assessment centres and aptitude tests. By focusing on these types of selection methods, employers may be signalling that they prefer to adopt the object approach to graduate talent, yet this has not been deduced empirically. It is the intention of this research to determine how employers decipher graduate talent, i.e. whether employers conceptualise talent using the object approach (something graduates are) or 
whether the "potential" of graduates is captured by the subject approach (something graduates have).

Another important contribution has been made by Cappelli (2008) who suggests that talent should be treated almost as a commodity (something that is bought, sold, transformed and used as inventory) and that strategies akin to supply chain management should be adopted in the form of a "talent-on-demand" approach. This approach outlines four principles that aim to address the risks of estimating demand for certain types of "talent", whilst also addressing the uncertainty of being able to access the appropriate supply of "talent" required to meet the challenges of creating organisational growth and sustainability. These four principles are 1) to make and buy talent to manage risk, 2) to adapt to uncertainty in talent demand, 3) to improve the return on investment in developing employees, and 4) to preserve the investment by balancing employer-employee interests. To address these principles Capelli outlines a number of recruitment, development and retention strategies that can be applied to the identified talent pools, but given the challenges of the graduate cohort (discussed further below), the priority placed upon addressing these principles and the challenges associated with achieving them may differ considerably to other talent pools. For example, employers focus more on the "potential" of graduates to develop into high performers, and as a result more emphasis will naturally be placed upon the development or "making" of graduate talent. But given the increasingly uncertain nature of the business environment and therefore the uncertainty associated with the type of skills and knowledge required for the organisation to grow, questions arise about how developing graduate talent fits into the overall priorities for meeting organisational objectives. Thus this research aims to understand the priorities organisations have in relation to recruiting, developing and retaining graduate talent to achieve organisational objectives. 


\section{Graduate Recruitment, Development and Retention}

TM involves a variety of practices and activities, ranging from employer branding, recruitment and selection, succession planning, training and development and retention management, but the manner in which these practices are prioritised by organisations will depend upon the TM approach adopted and to whom they are directed. For example, when taking an exclusive subject approach, appropriate development strategies must be in place to ensure that the correct skills and competencies are developed within the "talent pipeline" so that positions of pivotal importance can be filled by the most capable of employees. On the other hand, when taking an exclusive and object approach, attracting, recruiting and retaining innately talented individuals may be deemed important for gaining competitive advantage and therefore activities such as employer branding may be viewed as an important aspect of drawing talent into the organisation and away from competitors.

When deciding upon the most appropriate TM practices for graduates, a number of specific challenges can arise. For example, given graduates' relative inexperience, there are often challenges in developing this cohort of employees to the standards expected by the organisation. Literature on graduate recruitment, development and retention has been dominated with concerns related to the employability of graduates. Employability can be described in various ways ranging from the skills essential for obtaining a job, such as interview preparation, to the skills needed to carry out a job effectively, such as generic abilities, personal attributes and specific/subject abilities (Helyer and Lee, 2014). It can also encompass an individual's propensity to gain and maintain employment, and be effective in the workplace to the benefit of themselves, their employer and the wider economy (Harvey, 2001; Wilton, 2011). Various authors 
have commented that for too long there has been a discrepancy between the skills and competencies employers expect from graduates and those that graduates actually possess (Crebert, Bates, Bell, Patrick and Cragnolini, 2004; Eisner, 2010; Rae, 2007; Raybould and Sheedy, 2005).

Several authors (De la Harpe, Radloff and Wyber, 2000; Medhat, 2003) have also argued that employers increasingly perceive that higher education institutions are not producing "work ready" graduates (Harvey and contributors 2003, p. 1) and that, although graduates may have degree specific knowledge, they do not have the soft skills needed for the work environment. More recent research identifies soft skills such as team working, communication, adaptability and problem-solving to be key (European Commission, 2010; Eisner 2010; Huq and Gilbert, 2013). It is these skills and qualities which are deemed to differentiate high potential graduates from others within their peer group. As a result, employers have become much more interested in transferable skills, which are typically softer in nature (communication, problem solving and team working), and personality as opposed to job-oriented skills and knowledge.

Activities for recruiting and developing graduates are also becoming more important for organisations that wish to attract and retain the best graduate talent. There is growing acceptance amongst HR scholars and practitioners that the characteristics of recent graduates, many of whom belong to "Generation Y" (i.e. millennials who were born between the early 1980s and early 2000s), need to be understood to ensure that recruitment and development activities are effective. Compared to other generations, research completed by Luscombe, Lewis and Biggs (2013) and Terjesen et al., (2007) reveal that Generation $\mathrm{Y}$ have unique attitudes, expectations and motivations. For example, it was found that they have expectations of extensive training and 
development opportunities as well as the desire for long-term career progression, variety in work, opportunities to collaborate, and to work in a dynamic, forward-looking business that embraces advanced technologies. Furthermore, it was found that although Generation Y employees have a deep interest in charitable and socially responsible actions, they are also concerned with more personal issues (Senior and Cubbidge, 2010). For example, whilst Generation Y reported their desire to undertake challenging assignments, they were less inclined to enter into such roles unless the organisation could offer them the opportunity for a fair and honest assessment of how participation might affect future career aspirations. Similar findings were reported by ILM (2011) who found that Generation Y employees desired managers with a coaching style that could provide useful, honest and informal feedback regarding performance and prospects in the organisation.

Gaining a sense of fulfillment and enjoyment at work was also noted as a key motivator for these employees and that working time flexibility was instrumental in achieving this. The related issue of work life balance has been noted by Ashtana (2008) who argue that unlike their Baby Boomer or Generation $\mathrm{X}$ peers, Generation $\mathrm{Y}$ employees place less emphasis upon salaries and much more emphasis on flexible working, time to travel and a better work life balance. Furthermore, ILM (2011) showed that although money was still a motivator for Generation $\mathrm{Y}$, the aspiration to progress into another role or to another organisation after two or three years was often more important.

Drawing from the career development literature, King (2003) contends that graduates often regard their first employment as a stepping stone to better roles and thus look for employers to offer development opportunities that will enhance their external 
employability. This is problematic for employers wishing to retain the best graduate talent. For example, developing programmes that aim to enhance the graduate's internal employability for promotion into key strategic positions is also likely to prepare them for an external route to career progression. Poor retention levels of graduates can be a concern for many employers given that, on average, they do not recoup the investment made in graduate level employees until the graduate spends a year in a senior strategic role, which is often not until their fifth year of employment (Beddingfield, 2005). Authors such as King (2003) have noted that one of the main reasons why highly talented graduates choose to move to another company is related to the lack of opportunities they receive for training, development and career progression.

Furthermore, Scholarios, Lockyer and Johnson (2003) contend that turnover and retention issues arise when initial expectations are not fulfilled in reality. Issues arise as employers find it increasingly difficult to meet such expectations. Ultimately, Beddingfield (2005) argues that it is this mismatch of expectations and a lack of preparation for the reality of working life that can cause a high churn rate amongst graduate employees.

In summary, employers are faced with a number of challenges in relation to graduate TM. They need to become much more aware of the types of skills (general, transferable and more specific) they require from graduates to capitalise on opportunities for organisational stability and growth, but they also need to understand how to attract the right graduates from the general labour market and how to retain them to maintain an internal graduate talent pool. In order to retain and maximise the potential of these graduates, employers need to develop strategies which will allow both the graduate and organisation to grow together, addressing the graduates' expectations 
for development and opportunity. If employers are able to understand this labour market reality they should be in a more favourable position to recruit and retain the right talent to fulfil their strategic objectives. Thus given the unique characteristics of recent Generation Y graduates this research aims to identify the specific challenges associated with recruiting, developing and retaining graduates and uncover the innovative or novel practices that employers use to overcome the challenges of managing the graduate talent pool.

\section{Methodology and Research Design}

A multiple case study approach was chosen to undertake the research for this study. Many authors have noted how a case study approach allows for an increase in the quality and quantity of data obtained and for the researcher to analyse relationships and social processes that is not possible via a quantitative approach (Yin, 2009; Gummesson, 1991). The organisations chosen for this study were selected through a purposeful sampling strategy after an initial meeting was held with the Careers Development Department of the University in which the researchers were employed. The purpose of this initial contact with the Careers Department was to help identify a range of multinational corporations and regionally based SME's (Small to Medium Enterprises) that had employed graduates recently. The Careers advisors were able to provide a list of organisations who met our initial sampling frame, which was organisations with more than one hundred employees, as it was felt they were more likely to have a dedicated HR function (Brewster, Wood, Croucher and Brookes, 2006) and may have considered TM strategies. Six organisations from various industries, including IT, Hospitality, Manufacturing (Aerospace), Charitable, Construction and Public Sector Healthcare, were identified as potential case study participants and 
invitation letters were sent to the HR Director/Manager. All of the organisations responded favourably to our request for access and preliminary interviews were set up with key personnel who could outline contextual issues within their organisations and advise us regarding further data collection.

Rather than simply rely on the managerialist perspective, our goal was to gain access to personnel who were involved in, and who were the recipients of graduate TM strategies. This included interviews with line and departmental managers, HR managers/advisors and graduate trainees/recruits. By including graduates in our data collection more consideration was given to how TM strategies are experienced and responded to by the "talent" to whom they are directed (Huan and Tansley, 2012). Thunnisen et al. (2013) argue that the current literature is relatively unitarist in perspective and thus, by gaining the graduate viewpoint, we were able to understand a wider and more pluralist perspective from the key stakeholders involved in the TM area. Table 2 below provides details of the case organisations, including a brief description about their context:

---Insert Table 2 about here----

The data collected was analysed using Eisenhardt and Graebner's (2007) guidelines on case study analysis. The aim of the data collection was to obtain insights into the priorities of these organisations in relation to their graduate TM strategies. The primary source for data collection was face to face interviews, although in some organisations archival data in the form of annual reports, strategy documents, trade and internal company magazine articles were also collated in order to provide information on graduate recruitment and development issues. Across the six case organisations, 
sixteen semi-structured and in-depth qualitative interviews were held with HR Managers, line managers who directly supervised graduates, and at least one graduate in each organisation who was working in a graduate position. The interviews typically lasted 60 minutes (with variations between 25 minutes and 80 minutes). Prior to data collection, an interview protocol was developed and an interview guide was designed based on the literature. This interview guide comprised questions on a number of issues including: graduate recruitment and development priorities in relation to the company's TM strategy; skills and competencies issues, changing graduate expectations and issues of retention. During the interviews respondents were encouraged to describe and share information about their experiences of organisational strategies and practices relating to those issues mentioned above.

In relation to data analysis, after the interviews were fully transcribed the research team analyzed the data to determine common factors and themes. The three authors coded the responses according to their relevance to the main research areas as discussed above. Consistent with the definition given by Silverman (2000, p. 123), we were able to "establish a set of categories and then count the number of instances that [fell] into each category". In essence this technique was designed to code the qualitative information and allowed us to ". . . make some analytic "sense" of raw data. Conventional methods of achieving this involve the coding of open-ended replies in order to permit comparison" (May 1993, p. 105). "Open coding” was used, which meant that each response was analyzed and the data were placed in emergent categories. Additionally, use was made of what Turner (1981) has called "axial" coding that allowed us to review and re-sort the data into sub-categories and establish linkages and relationships. As can be seen from the sub-headings in the findings section below, distinct themes emerged from the coding process. For example, retention emerged as a 
theme and from this general category several sub-categories "fell-out" of the data relating to, for example, the problem of meeting expectations and the design of training programmes.

After the raw data was analysed a series of individual case study reports were developed and presented to the organisations involved in the study. Further, as part of this analysis, follow-up meetings were undertaken with three out of the six HR managers with whom we had originally agreed research access to discuss common themes in the findings. In effect these meetings added another layer of data analysis and allowed us to ensure that the information we collected was externally valid. A key strength of this approach was that it allowed the triangulation of data from multiple informants in order to determine the key lessons that could be learned about graduate TM in this context. This analysis then formed the basis of the research findings, which are presented below.

\section{Findings \& Discussion}

This findings section is organised according to the research objectives presented above. For a full summary of findings from each of the six case studies in relation to these four research objectives (RO) see Table 3 below.

$$
\text { --- Insert Table } 3 \text { about here --- }
$$

\section{What is Graduate Talent?}

The first objective of this research was to ascertain what employers understood graduate talent to be. Detailed analysis of how each case organisation conceptualised graduate talent can be found in Table 3 within the RO1 column. One clear finding was that employers felt that graduates who are able to showcase their talent will have "the 
edge" in comparison to others in the graduate labour market. For example, when probed further upon this concept of having "the edge", the HR Manager from the Public Sector Organisation noted that there was now a clear expectation that graduates would have many of the softer, interpersonal skills, but that they would also be more strategically orientated and have the "drive to face new challenges, ... be people with fresh eyes."

Similarly in the Aerospace Organisation, the HR manager reiterated that it was critical for graduates to display the ability to give a "fresh" perspective on issues. In terms of what the other organisations desired regarding skills and competencies, responses were summed up by a line manager from the Hospitality Organisation who expected graduates to offer something "extra" in comparison to non-graduate staff. In this organisation, they did not have a specific graduate development programme, but the interviewee felt that graduates often displayed other abilities that could help the organisations address the specific challenges of that sector. For example, commenting on behavioural and technical competency requirements, the HR manager noted that "It's not enough any more to be bubbly, you need to pour a pint and upsell, pour a pint and [sell] a packet of nuts or a pint and [sell] a dinner, you need to maximise sales...graduates should be able to do that."

A similar picture emerged in the Construction Organisation where because of the organisation's strategy of contracting for more demanding clients in the retail sector, graduates were required to have a more comprehensive set of knowledge, skills and competencies at the recruitment stage. When we asked the line manager about the demands being placed upon their current graduates he sensed that a lot was now asked of them in an increasingly stressful and "fast paced" environment, which meant that the quality that was most valued was the ability to "deal with uncertainty and ambiguity." A similar perspective was found in the Charitable Organisation where the 
HR manager noted that the "ability to cope with uncertainty had become increasingly important over the last few years."

It is important to note that we found the term "talent" to be a subjective one, something which has been reiterated in the literature (see for example Tansley, 2011 and Huang and Tansley, 2012). When discussing graduate talent employers referred to the technical and specific skills that were important for their business: having the ability to think strategically; having the ability to deal with uncertainty; being career focused; being committed to further development: having some quality work experience (through placement or otherwise); having common sense and practical knowledge; having self-awareness, and confidence and initiative. However, the employers' conceptualisation of graduate talent was more nuanced and often based on intangible qualities or experiences that they could only sum up by "the edge".

The graduates interviewed were acutely aware of the need to promote those skills and competencies most sought by employers. For example, one of the graduates working in the Hospitality Organisation understood that he had to demonstrate both practical and more intangible qualities in his role, by exhibiting “... a good business mind,... and a good solid head on my shoulders, common sense ... I don't think I was employed because of my degree but more my experience, practical sense and capability to do the job." Meanwhile, another graduate from the Aerospace Organisation stated how it was essential that you "stand out through life experiences" in order to differentiate yourself from other graduates. He summed up the scenario by noting that "most grads have the same level of knowledge therefore selection is often based on other aspects."

The issue of "standing out from the crowd" was also noted when we explored the importance of work placements and internships. A key aspect for a number of the 
employers was an apparent change in attitude towards placements. In the past they would have been viewed as an "extra" but simply having a year's placement appeared to no longer be enough to impress prospective employers. For example, the HR manager from the Public Sector Organisation explained how they now took a much more analytical approach towards the placement experience: "Graduates think that just because they have their degree and a year's placement experience, that's enough. People who have actively sought work in their area will stand out. The good ones are very focused in terms of their career."

We found that employers dissected in more detail the graduate's placement and other work experience and their performance levels in order to inform recruitment decisions. The line manager from the Construction Organisation summed up the use of their placement opportunities as being "a one year-long interview”. Building on this perspective, the line manager from the Aerospace Organisation made a point of noting that their senior managers were openly critical of the fact that some university courses did not offer placement opportunities. This had led to frustration because he felt it was obvious to all stakeholders that engineering placements were “... important in developing graduates for the world of work." Indeed he went on to describe how the organisation had begun to liaise more closely with local Higher Education Institutes (HEIs) in order "to develop the courses that we could benefit from ... we need more specific skills sets from graduates and specific knowledge. This has been difficult to acquire and thus we are striving to work with universities."

In summary, research objective one was designed to identify how the various interviewees conceptualised graduate talent. When considering Gallardo-Gallardo et al.'s (2013) typology of talent approaches using a subject or object lens, we suggest that employers take a blended approach to graduate TM that is contingent on the 
information employers have about the performance potential of graduate candidates. We found that judging the graduates' past performance levels in the workplace is becoming an increasing priority for employers as they are now looking for more tangible evidence of the candidate's placement and work experience. This demonstrates that employers would prefer to adopt a subject approach when identifying talent (i.e. based on performance or potential to perform) but they recognise that this is not always feasible given the lack of experience of many graduate applicants.

On the other hand, our interviews with employers also indicated that without the tangible information about the performance potential of graduate candidates, the employers look for something more nuanced within the graduate to inform their recruitment decision. Ultimately employers were looking for something "extra", something "fresh", the ability to "stand out from the crowd" and someone with an “edge". This equates to an object approach as described by Gallardo- Gallardo et al (2013) in which talent is conceptualised as the innate characteristics of people and not just what they do or how they behave. The Hospitality and Charitable organisations however conceptualised talent using the subject approach more so than the object approach. They did not necessarily target graduates but instead they invested in the development of individuals who already worked within the organisation and who were identified as performing to a high standard and displaying an "edge", some of whom were graduates in non-graduate positions and some who were volunteers.

We suggest that the degree to which graduate talent is conceptualised using an object or subject approach is contingent on the availability of tangible information about the graduate's past performance or potential to perform, but given the lack of experience that graduates display, employers who target graduates may be more 
compelled to adopt the object approach, which inherently carries more risk in terms of graduates meeting performance expectations.

\section{Organisational Priorities for Graduate Talent Management}

The second research objective was designed to understand the priorities organisations had in relation to recruiting, developing and retaining graduate talent to achieve organisational objectives. Detailed analysis of these priorities can be found in Table 3 in the column dealing with RO2. Our findings suggest that the challenges of sustaining competitiveness and creating business growth, and the skills and experience required to facilitate this, were the most influential factors for graduate TM. All six organisations studied mentioned the constantly changing business needs, the impact of such turbulence on the opportunities available for graduates and the need to acquire graduates with certain skills and experience to fill, or have the potential to fill, pivotal positions. The interviewees from the Construction, IT, Public Sector and Aerospace Organisations admitted that although many of these pivotal positions were out of the reach of recent graduates due to their lack of skills and experience, the opportunities they offered from within formal graduate programmes were still a vitally important component of their TM strategy. These organisations reiterated the importance of having a presence in the graduate labour market to ensure that fresh and up-to-date skills and talents could be maintained. As the HR manager from the Public Sector Healthcare Organisation commented:

“We are now running new OD/HR and engineering schemes. Procurement just started this year and IT is starting next year. The management schemes continue to run because it's all about talent management, getting folk into the organisation with drive to face new challenges". 
However, an interesting trend from our discussions was the apparent redirection of resources from traditional graduate trainee programmes towards the recruitment of more experienced professionals whose expertise could help deal with more immediate business needs. Therefore the overall approach to TM in these organisations focused on attracting and recruiting individuals with more advanced, knowledge-based and technical skills.

Thus, although the importance of graduate talent was recognised, it was also acknowledged that recent graduates were often unable to deliver the skills and expertise that were needed. The IT HR Manager commented that the reduction in graduate recruitment was not influenced by issues of affordability, but rather by the need for specific skills and experience which graduates were unable to offer, "we need more experienced people, so figures for graduate recruitment are not driven by the economy, they are driven by business need ... we don't have the luxury of bringing in so many graduates now".

The key aspect to this finding was that at least three of the case organisations acknowledged that they needed to "buy in" the necessary talent and experience to fill positions of pivotal importance, at the expense of developing and promoting from within. The priority of the Construction, Aerospace and IT organisations in particular was to maximise the opportunities for growth and attract individuals who could make an immediate impact to the organisation. It was felt by the interviewees that graduates frequently needed more support and time commitment to allow them to fully contribute. For example, a line manager from the Aerospace Organisation commented how the "recruitment of recent grads is restricted due to necessary mentoring and development required... in order to fulfil business needs... the business relies heavily on experienced 
subcontractors now". Therefore, although employers recognised the importance of continuing to recruit graduate level employees, current business demands frustrated opportunities for developing them fully, with time and resource commitments needed to mould graduates to the required standard at a premium. However, although graduate places were more limited, we also noted how those organisations which continued to offer graduate opportunities employed a more selective approach to recruitment to ensure that they could deliver what the HR Manager from the Public Sector Organisation described as better "value for money".

Therefore in line with Cappelli's (2008) assertion, three of the employers interviewed chose to both "buy" and "make" talent to manage the risk of shortfalls in expertise and experience. Due to the aforementioned time and resource constraints, priority was given to "buying-in" relevant skills and experience over developing graduates and this impacted on the numbers recruited. This was a predominant feature of the growth organisations and for those sectors with skills shortages. By focusing on graduate TM an exclusive approach is inherent however given the challenges associated with graduates and their development needs, these organisations have increased the exclusivity of their graduate talent programmes to reduce the risk of managing talent inefficiently. In terms of their graduate talent programmes, they have had to become more exclusive and therefore the criteria to join such programmes has been further refined. Again this led some of the interviewees to reiterate that having the "edge" was now essential for graduates if they were to be considered for one of the prised places.

Skill shortages were less of a feature in the Charitable and Hospitality organisations and thus a more improvised approach to TM could be adopted. These organisations did not specifically address graduate TM but still adopted an exclusive approach to TM by acknowledging the contribution from specific individuals who 
displayed "an edge" regardless of their qualification. However this approach was not part of an over-arching TM strategy, but was delivered in a more ad hoc or improvised manner. For example, in the Charitable Organisation the emphasis on the recruitment of graduates had changed. Issues connected to a lack of experience and skill requirements as well as the challenge of training, coaching and mentoring graduates were given as reasons as to why this organisation no longer focused specifically on the graduate labour market, but yet they were still open to the idea of encouraging graduate volunteers to contribute to the organisation. The HR manager from the Hospitality organisation also adopted a more informal view of how graduates could be used to develop their talent pool. A key focus of this organisation was to open opportunities to a range of employees, many of whom were graduates employed in non-graduate positions, if they could demonstrate they had the appropriate skills and attitudes to progress their career in the hospitality business.

"We have a manager who left in the final year of her law degree having decided that it wasn't for her and that the hospitality industry was the way forward for her. Our induction process is very like, you might not be here for long, or you might be here for a considerable length of time-whatever, there is a clear progression for you. If you show potential and skills you will be promoted. It's very much a level playing field for graduates and non-graduates"

These findings suggest organisations will reconsider their graduate TM approach when faced with specific business challenges or opportunities. Given that this research was conducted during a period of economic instability, it may have been assumed that organisations could simply not afford to recruit graduates. However, our findings suggest that cost was not the predominant factor and that the rationale for reducing 
graduate numbers was more strongly related to a perceived lack of skills and experience. With this in mind our third objective was designed to explore in more detail the challenges, and the associated solutions, which employers face in terms of graduate TM.

\section{Challenges of addressing graduate TM}

Detailed analysis of the challenges associated with addressing graduate TM can be found in Table 3 within the column RO3. One of the key findings was the concerns employers raised about graduate employability. For example, the line manager from the Aerospace Organisation summed up that graduates were not always "work ready". He noted that in particular they needed "better presentation skills, interpersonal skills. ... better understand the working professional environment. They are sometimes quite undisciplined. Some don't have the confidence to ask questions or share ideas. They are too quiet."

At least half of the organisations still had graduate level positions that remained hard to fill. For example, the HR manager from the IT Organisation bemoaned the fact that, in her experience, "IT companies in general are all saying the same thing about the lack of IT graduates. Even in years to come when we are looking for experienced people there will still be problems." With a key strategy of growth and expansion, this organisation had changed its approach to graduate recruitment and selection. Where it had historically tended to rely heavily on recruiting from local universities, recently it had begun to look towards other national and international sources.

A number of other challenges and concerns were noted by the case study organisations. For example participants from the Construction Organisation commented that retaining graduate talent in a tough, uncompromising and highly 
stressful environment was a major challenge, whilst for the Aerospace, IT and Hospitality organisations managing expectations regarding the provision of development opportunities, or simply being able to find enough graduates with the specific skills set needed were pressing concerns.

Ultimately many of these challenges are associated with managing Generation Y. For example, this cohort may not have the loyalty to the organisation that other generations in the past may have displayed. The line manager from the IT Organisation noted how newer graduates were more inclined to move to competitors for new opportunities despite having been the recipients of a great deal of developmental resource. Similarly in the Hospitality and Aerospace organisations it was found that some Generation Y graduates were reluctant to perform roles which they perceived did not fully utilise their skills and talent. Interestingly when we probed for more details regarding these issues, the managers we interviewed noted that in some cases graduate recruits were ill equipped to perform well in higher level roles and had to be more patient and prepared to up-skill significantly.

In this research it was noted that there were clear challenges associated with the employability, attitude and values of Generation Y graduates. Thus the employers' expectations in relation to the graduates' performance were often not met and unsurprisingly several had adopted a more cautious approach to graduate recruitment and development by pursuing a more exclusive approach. Given the challenges of the Generation Y graduates this reinforced the importance for employers to look for graduates who were perceived to possess the "edge". 
The IT Organisation employed innovative recruitment and selection methods. The HR manager described how they utilised online videos to further inform and up-skill graduate recruits in advance of officially starting with the company. It was also noted that this initiative was now so successful in the preparation of new graduate recruits that there were plans to fully implement it across all talent groups of the organisation. As well as looking at the early stages of employment, there appeared to be an excellent development structure in place which was designed to give graduates access to extensive coaching, career development planning, shadowing, independently-directed learning, and visits to customer organisations and international office locations. This strategy was designed to respond to the motivation, expectations and values of Generation Y who were described by the HR manager as typically having a "two-year, itchy feet thing”. The HR Manager observed how these novel practices to graduate recruitment and development had allowed them to achieve the positive outcome of retaining graduates for five years on average.

In relation to the Public Sector Organisation, it was observed that efforts had been made to restructure the graduate development scheme to allow graduates to obtain experience in all relevant functional areas. The benefit of creating more structured graduate schemes was also recognised within the Aerospace organisation which had recently introduced many changes to its scheme in the hope that the 50\% annual churn of engineering graduates would be reduced. The HR Manager noted how they had traditionally developed their graduate intake within specific chosen functional areas. However, the organisation now recognised the importance of offering a more holistic programme that could offer the best graduates more exposure to other business areas. This change was in response to two factors. Firstly, the organisation realised that when progressing from the existing graduate development programme, the opportunities for 
career progression were limited. Secondly, the graduates themselves communicated their dissatisfaction with the design of the programme. They had joined the organisation with the expectation that they would receive a varied exposure to the business and when these expectations were not met some graduates left.

Such scenarios are commented upon by Cappelli (2008) who contends that for organisations to address talent retention issues they must ensure that their development programmes "balance employee / employer interests". Cappelli proceeds to suggest that engaging employees in decisions about their progression or giving them choice about how they wish to develop will have a positive effect on retention. The Aerospace organisation was clearly aware of this important principle and developed its graduates more broadly and in line with more holistic organisational behaviours and competencies, as opposed to more narrowly defined functional requirements. Thus, graduates were better equipped, had more choice and freedom to apply for a greater variety of internal positions and thus could direct their own career progression more effectively. Such a development strategy is particularly important for "Generation Y" graduates who are much more au fait with issues surrounding career progression than perhaps their Generation X colleagues (Luscombe et al., 2013). Indeed, after making changes to the development programme, the Aerospace organisation realised a significant improvement in the retention of graduates. Furthermore, current graduates on the revised programme seemed to be very satisfied with the more varied development journey stating: "it is a very structured programme - the big thing about this organisation is about knowing the wider business before knowing exactly where you want to go. You need to know this before knowing how to develop further."

The practices in use within the Construction Organisation were also designed to improve retention rates, where the setting of challenging "stretch targets" for the most 
capable graduates appeared to have enhanced their motivation and resulted in the very best staying with the organisation, regardless of other opportunities within the market. For example, a graduate from this organisation who had responsibility for new site development for large retail organisations noted how his role was extremely challenging and how he had to "deal with uncertainty because there was real pressure in working with organisations like [large UK supermarket chain]" who set demanding targets and "don't accept any excuses ... you need to be able to explain why exactly there are any delays in construction of new sites". The pressures which this graduate experienced are in line with the third principle which Cappelli (2008) outlines. In order to improve the return on investment on developing employees, Cappelli suggests that employees must share in the costs of development. In the Construction Organisation graduates who are under pressure to meet "stretch targets" have to push themselves to meet the expectations of their employers and having then impressed their employers, the graduates seemed reluctant to leave, having invested the effort in proving themselves.

\section{Conclusions, Contribution and Implications for Practice}

This study has examined the distinguishing features of graduate TM in a number of UK case organisations. Overall there are three main conclusions. Firstly, our primary objective was to establish how the employers within our case studies conceptualised graduate talent. Employers described a number of skills and attributes that they look for in graduates, but defining graduate talent was more nuanced and could only be summed up as having an "edge". This aligns with the "object" approach outlined by GallardoGallardo et al. (2013), i.e. something that the graduates have as opposed to something which they demonstrate they are. However we suggest that graduate employers adopt 
an object approach when the subject approach is inadequate for making judgements about the performance potential of graduates, especially at the recruitment stage. There are a number of drawbacks to the object approach. The employers we spoke with described talent as something intangible, "an edge", but it is unclear how this translates to performance levels in the organisation. There was great dissatisfaction about the "work-readiness" of graduates and thus we suggest that identifying graduate talent using the object approach may be sub-optimal in comparison to the subject approach.

There are a number of implications for this finding. Given that employers may prefer to approach the identification of talent using the subject approach, they need to have more information about the candidate's ability to perform in the workplace (a reality that aptitude tests and assessment centres may not address fully). The employers we spoke to have taken a greater analytical view of the placement and work experience of graduates and some have also invested greater effort in working with universities to design university degree programmes that will address the knowledge and skills required by employers. However employers need to find ways to identify and evaluate the performance potential of graduates and thus an important recommendation for employers is to develop stronger links, not only with university personnel but also with university students as they progress through their course. Providing placement opportunities is a vital aspect of learning about graduates' performance potential, but a range of other initiatives could be considered that strengthen relationships between employers and university students, such as internships, summer placements, and involvement in university assessments etc.

Our second conclusion relates to the recruitment, development and retention of graduate talent to achieve organisational objectives. By focusing on the graduate talent 
pool, employers naturally adopt an exclusive approach to TM and we found that for those organisations that had graduate development programmes in place, the approach to graduate TM was characterised by greater exclusivity, where the number of graduates recruited and developed was reduced in favour of "buying in" or recruiting experienced personnel who could make an immediate impact. Although the importance of graduate talent was still recognised and the organisations we spoke with made systemic changes to their development programmes to improve the quality of graduate talent, the immediate need for particular skills and knowledge to meet organisational objectives was seen to be a greater priority. The decision to reduce graduate numbers was further compounded by the many challenges that graduates presented when entering the world of work in terms of the investment and effort required on the part of employers to develop graduates to a standard where performance expectations are met. These challenges were often linked to the characteristics associated with Generation $\mathrm{Y}$ employees.

Thus, although "making" talent from the graduate talent pool was still deemed an important TM activity, choosing to "buy in" talent to manage the risk of talent supply and demand was of greater priority particularly when operating in a business environment that demanded more advanced skills. However, when it comes to graduate TM in sectors that demand less advanced skills (such as the hospitality and charitable organisation) choosing to adopt a more improvised approach to managing graduate talent pools seemed to be preferred. Irrespective of the sector or structure of TM activities, we found that employers adopted an exclusive approach to selecting graduates for talent pools which was based on the criteria of "the edge".

There are two key implications of this second conclusion. Firstly, although graduates may be selected for talent pools because they have "the edge" there is still a 
clear need for employers to invest in the development of graduates so that their potential can be improved or, their "edge" can be "sharpened". And secondly, if employers across the board continue to de-invest in graduate recruitment and development, grave concerns may arise about the supply of talent to fill pivotal positions within organisations in the long term, particularly in sectors that require more advanced skills (Capelli, 2008). It would be wise for organisations that have reduced the scale of their structured graduate development programmes to be cognisant of the graduate talent across the entire organisation and adopt in addition to the structured graduate development programmes, a more improvised and flexible approach to developing the graduate talent pool.

Our final conclusion relates to the novel practices that employers have adopted to address graduate TM. The study identified a number of initiatives which were developed by employers to address the idiosyncratic characteristics of Generation $\mathrm{Y}$ graduates. For example, online induction videos were used to upskill graduates prior to commencing employment, more opportunities to broaden the experience of graduates were offered, more choice of career path was offered and structured mentoring and coaching programmes were initiated. Many of these practices were introduced in response to poor graduate retention rates. Thus, although employers are taking a more selective approach to graduate recruitment, they must still continue to invest in opportunities offered to graduates to address retention and ensure an appropriate return of investment. This is becoming much more challenging given the different characteristics of Generation $\mathrm{Y}$ graduates compared to other generations in the workforce. An implication of this last conclusion is that employers must evaluate their 
graduate talent pool and reflect on the suitability of the TM practices for the recent graduate labour market, particularly as this market is made up largely of Generation Y.

This study contributes to the knowledge base of $\mathrm{TM}$ as it reveals the distinguishing features of TM for graduates. Given that graduates have unique characteristics, this study reaffirms the need for organisations to adopt a differentiated TM approach, but it also raises questions about why talent is conceptualised in the manner it is. Gallardo-Gallardo et al. (2013) discuss talent in terms of an object or subject approach, but when considering graduates this study proposes that it is preferable for employers to judge graduate talent based on performance potential (subject approach). However, the characteristics of graduates and lack of performance information compel employers to judge talent based on more nuanced and intangible qualities that they call "the edge".

\section{Avenues for future research and limitations of the study}

This research addresses the matter of differentiating talent pools by specifically examining graduates and taking account of the unique characteristics and associated challenges and opportunities that this talent pool exhibits. However, we acknowledge there are a number of limitations to this research. Firstly, our data collection was limited to a few key personnel within a limited number of cases. Broadening the data collection to involve more graduates from a range of backgrounds, as well as more line managers would have strengthened the reliability and validity of our findings. Secondly, we have not compared the TM practices used for graduates with another category of employee. An avenue for further research would be to perform a comparison of our data surrounding graduate talent with information on how talent is conceptualised when considering different employee talent pools. We recommend that similar research is 
conducted on other categories of employees such as cohorts of apprentices, middle or senior managers, or sub groups of employees across different areas of the business. By exploring TM and considering different cohorts of employees and their characteristics, the literature can be enriched with further ideas about how and why talent is conceptualised in the manner it is. By considering a range of employee characteristics and their associated challenges and opportunities for TM, researchers and practitioners will be better informed about how strategies can be differentiated to produce improved outcomes.

\section{References}

Beddingfield, C. (2005). Transforming the ROI of your graduate scheme, Industrial and Commercial Training, 37, 199-203. DOI 10.1108/00197850510602114

Biswas-Diener, R., Kashdan, T.B., \& Minhas, G. (2011). A Dynamic Approach to Psychological Strength Development and Intervention, The Journal of Positive Psychology, 6, 106-118. DOI: 10.1080/17439760.2010.545429

Boudreau, J.W., \& Ramstad, P.M. (2005). Talentship, Talent Segmentation, and Sustainability: A New HR Decision Science Paradigm for a New Strategy Definition, in M. Losey, S. Meisinger and D. Ulrich, Hoboken (Eds.), The Future of Human Resource Management, NJ: Wiley \& Sons, pp. 293-303.

Brewster, C., Wood, G., Croucher, C., \& Brookes, M. (2006). What Determines the Size of the HR Function? A Cross-National Analysis, Human Resource Management, 45, 3-21. DOI: 10.1002/hrm.20093

Buckingham, M., \& Vosburgh, R. (2001). The 21st century human resources function: It's the talent, stupid!, Human Resource Planning, 24, 4, 17-23. ISSN: 01998986 
Cappelli, P. (2000). A Market-Driven Approach to Retaining Talent, Harvard Business Review, 78, 103-111. ISSN: 00178012

Cappelli, P. (2008). Talent Management for the twenty-first century, Harvard Business Review, 86, 3, 76-81. ISSN: 00178012

Collings, D. G. \& Mellahi, K. (2009). Talent Management: A review and research agenda, Human Resource Management Review, 19, 304-3013. DOI: 10.1016/j.hrmr.2009.04.001

Crebert, G., Bates, M., Bell, B., Patrick, C. \& Cragnolini, V. (2004). Ivory Tower to Concrete Jungle Revisited, Journal of Education and Work, 17, 47-70. DOI: $10.1080 / 1363908042000174192$

Davies, B., \& Davies, B.J. (2010). Talent Management in Academies, International Journal of Educational Management, 24, 418-426. DOI: $10.1108 / 09513541011055983$

De la Harpe, B., Radloff, A. \& Wyber, J. (2000). Quality and generic (professional) skills, Quality in Higher Education, 6, 231-43. DOI:

$10.1080 / 13538320020005972$

Dries, N. (2013). The psychology of talent management: A review and research agenda, Human Resource Management Review, 23, 272-285. DOI: 10.1016/j.hrmr.2013.05.001

Eisner, S. (2010). Grave new world? Workplace skills for today's college graduates, American Journal of Business Education, 3, 9, 27-50. 
Eisenhardt, K.M. \& Graebner, M.E. (2007). Theory Building from Cases: Opportunities and Challenges, Academy of Management Journal, 50, 25-32. DOI: 10.5465/AMJ.2007.24160888

European Commission (2010). Employers' perception of graduate employability, Flash EB Series No 304, Hungary: The Gallup Organization.

Festing, M \& Schafer, L. (2014). Generational challenges to talent management: A framework for talent retention based on the psychological-contract perspective, Journal of World Business, 49, 262-271. DOI: 10.1016/j.jwb.2013.11.010

Fleming, J.H. \& Asplund, J. (2008). Understanding the nature of talent; managers must distinguish what's innate in their employees (talent) from what can be changed or acquired (knowledge and skills)', Gullup Management Journal, 10 January 2008.

Gagne', F. (2004). Transforming Gifts into Talents: The DMGT as a Developmental Theory, High Ability Studies, 15, 119-147. DOI:10.1080/1359813042000314682

Gallardo-Gallardo, E., Dries, N., \& González-Cruz, T. (2013). What is the meaning of 'talent' in the world of work?, Human Resource Management Review, 23, 290300. DOI: 10.1016/j.hrmr.2013.05.002

Garavan, T. \& Morley, M. (1997). The socialisation of high potential graduates into the organization: Initial expectations, outcomes and experiences, Journal of Managerial Psychology, 2, 118-137. DOI: 10.1108/02683949710164208

Gummesson, E. (1991) Qualitative methods in management research, Newbury Park, CA: Sage. 
Harvey, L. (2001) Defining and Measuring Employability, Quality in Higher Education, 7, 97-109. DOI: 10.1080/13538320120059990

Harvey, L. \& Contributors (2003), Transitions from higher education to work, Briefing Paper: Centre for Research and Evaluation, Sheffield Hallam University (with advice from Enhancing Student Employability Co-ordination Team and Learning and Teaching Support Network Generic Centre colleagues) Available from: http://www.qualityreserchinternational.com/ese/relatedpubs/Transition\%20from \%20HE\%20into\%20work.doc [Accessed 21 ${ }^{\text {st }}$ Dec 2010].

Heyler, R. \& Lee, D. (2014). The role of work experience in the future employability of higher education graduates, Higher Education Quarterly, 68, 348-372. DOI: 10.1111/hequ. 12055

Huang, J., \& Tansley, C. (2012). Sneaking through the Minefield of Talent Management: The Notion of Rhetorical Obfuscation, The International Journal of Human Resource Management, 23, 3673-3691. DOI: $10.1080 / 09585192.2011 .639029$

Huq, A. \& Glbert, D. (2013). Enhancing graduate employability through work-based learning in social entrepreneurship: A case study, Education and Training, 55, 550-572. DOI: 10.1108/ET-10-2011-0097

Iles, P., Preece D. \& Chuai, X. (2010). Talent Management as a management fashion in HRD: Towards a research agenda, Human Resource Development International, 13, 125-145. DOI: $10.1080 / 13678861003703666$

ILM (2011). Great Expectations: Managing Generation Y, London: Institute for 
Leadership and Management and Ashridge Business School.

Kim, C.H. \& Scullion, H. (2011). Exploring the links between corporate social responsibility and global talent management: A comparative study of UK and Korea, European Journal of International Management, 5, 501-523. DOI: 10.1504/EJIM.2011.042176

King, Z. (2003). 'New or traditional careers? A study of graduates' preferences', Human Resource Management Journal, 13, 5-28. DOI: 10.1111/j.17488583.2003.tb00081.x

Lepak, D. P., \& Snell, S. A. (1999). The human resource architecture: Toward a theory of human capital allocation and development, Academy of Management Review, 24, 31-48. DOI: 10.5465/AMR.1999.1580439

Lepak, D. \& Snell, S. (2002). Examining the Human Resource Architecture: The Relationships among Human Capital, Employment, and Human Resource Configurations', Journal of Management, 28, 517-543. DOI: $10.1177 / 014920630202800403$

Lewis, R. E. \& Heckman, R. J (2006). Talent Management: A Critical Review, Human Resource Management Review, 16, 139-154. DOI: 10.1016/j.hrmr.2006.03.001

Luscombe, J., Lewis, I. M. \& Biggs, H. C. (2013). Essential elements for recruitment and retention: Generation Y, Education and Training, 55, 272-290. DOI: $10.1108 / 00400911311309323$

May, T. (1993). Social Research: Issues, Methods and Process, Buckingham: OU Press. 
McDermott, E., Mangan, J \& O’Connor, M. (2006). Graduate Development programmes and satisfaction levels, Journal of European Industrial Training, 30, 456-471. DOI: 10.1108/03090590610610688834

Medhat, S. (2003). A new beginning for a strained relationship, Times Higher Education Supplement, 24 January, p.18.

Mellahi, K. \& Collings, D.G. (2010). The barriers to effective global talent management: the example of corporate élites in MNEs, Journal of World Business, 45, 143-9. DOI: 10.1016/j.jwb.2009.09.018

Minbaeva, D. \& Collings, D. G. (2013). Seven myths of global talent management, The International Journal of Human Resource Management, 24, 1762-1776. DOI: $10.1080 / 09585192.2013 .777539$

ONS (Office of National Statistics) (2012). Graduates in the Labour Market, London: ONS. Available from: http://www.ons.gov.uk/ons/dcp171776_259049.pdf

Oppong, N.Y. (2013). Talent management: A bundle of hurdles, Public Policy and Administrative Research, 3, 8, 63-73. ISSN (Paper) 2224-5731

Pfeffer, J. (2001). Fighting the War for Talent is Hazardous to Your Organization's Health, Organizational Dynamics, 29, 248-259. DOI: 10.1016/S00902616(01)00031-6

Rae, D. (2007). Connecting enterprise and graduate employability: challenges to the higher education culture and curriculum?, Education and Training, 49, 605-619. DOI: $10.1108 / 00400910710834049$ 
Raybould, J. \& Sheedy, V. (2005). Are graduates equipped with the right skills in the employability stakes?', Industrial and Commercial Training, 37, 259-263. DOI $10.1108 / 00197850510609694$

Scholarios, D., Lockyer, C. \& Johnson, H. (2003). Anticipatory socialisation: the effect of recruitment and selection experiences on career expectations, Career Development International, 8, 182-197. DOI: 10.1108/13620430310482562

Senior, C. \& Cubbidge, R. (2010). Enhancing employability in the "ME generation", Education \& Training, 52, 445-449. DOI: 10.1108/00400911011068405

Shaw, S. \& Fairhurst, D. (2008), 'Engaging a new generation of graduates', Education and Training, 50, 366-78. DOI: 10.1108/00400910810889057

Silverman, D. (2000). Doing qualitative research: A practice handbook. London: Sage.

Stahl, G.K., Bjorkman, I., Farndale, E., Morris, S.S., Paauwe, J., Stiles, P., Trevor, J., \& Wright, P.M. (2012). Six Principles of Effective Global talent management, MIT Sloan Management Review, 53, 24-32.

Tansley, C. (2011). What do we mean by the term "talent" in talent management?, Industrial \& Commercial Training, 43, 266-274 DOI: $10.1108 / 00197851111145853$

Terjesen, S., Vinnicombe, S. \& Freeman, C. (2007). Attracting Generation Y graduates: Organizational attributes, likelihood to apply and sex differences, Career Development International, 12, 504-522. DOI:

$10.1108 / 13620430710821994$ 
Thunnissen, M. Boselie, P. \& Fruytier, B. (2013). A review of talent management: infancy or adolescence?, The International Journal of Human Resource Management, 24, 1744-1761. DOI: 10.1080/09585192.2013.777543

Turner, B.A. (1981). 'Some practical aspects of qualitative data analysis: one way of organising the cognitive processes associated with the generation of grounded theory', Quality and Quantity, 15, 225-247. DOI: 10.1007/BF00164639

Vaiman, V., Scullion, H., \& Collings, D. (2012). Talent Management Decision Making, Management Decision, 50, 925-941. DOI: 10.1108/00251741211227663

Valverde, M. Scullion, H. \& Ryan, G. (2013). Talent Management in Spanish medium sized organizations, The International Journal of Human Resource Management, 24, 1832-1852. DOI: 10.1080/09585192.2013.777545

Wilton, N. (2011). Do Employability Skills Really Matter in the UK Graduate Labour Market? The Case of Business and Management Graduates, Work, Employment and Society, 25, 85-100. DOI: 10.1177/0950017010389244

Yin, R.K. (2009). Case Study Research: Design and Methods, (4th Ed). Thousand Oaks, CA: Sage. 
Table 1: Approaches to talent management (Gallardo-Gallardo et al. 2013)

\begin{tabular}{|l|l|}
\hline Inclusive and Subject Approach & $\begin{array}{l}\text { Talent management is all-encompassing } \\
\text { that is no different from HRM }\end{array}$ \\
$\begin{array}{l}\text { A broad range of talent management } \\
\text { practices applied to a broad range of } \\
\text { people }\end{array}$ & \\
\hline $\begin{array}{l}\text { Inclusive and Object Approach } \\
\text { Appreciates the potential of a broad } \\
\text { range of people and focuses on } \\
\text { development activities in order to } \\
\text { maximise potential }\end{array}$ & $\begin{array}{l}\text { Talent management resembles human } \\
\text { resource development }\end{array}$ \\
\hline $\begin{array}{l}\text { Exclusive and Subject Approach } \\
\begin{array}{l}\text { Focuses solely on a select few who have } \\
\text { been identified to fill pivotal positions } \\
\text { because of high performance or high } \\
\text { potential. }\end{array}\end{array}$ & $\begin{array}{l}\text { Talent } \\
\text { management development or succession } \\
\text { planning. }\end{array}$ \\
\hline $\begin{array}{l}\text { Exclusive and Object Approach } \\
\text { Focuses on giving opportunities to a } \\
\text { select few who have been identified as } \\
\text { being differentially different in terms of } \\
\text { ability, motivation and commitment. }\end{array}$ & $\begin{array}{l}\text { Talent management is about tailoring } \\
\text { opportunities for specific individuals } \\
\text { deemed to have 'innate talent' }\end{array}$ \\
\hline
\end{tabular}


Table 2 - Interviews Conducted

\begin{tabular}{|c|c|c|}
\hline Organization & Interviewees & $\begin{array}{c}\text { Graduate } \\
\text { Programme }\end{array}$ \\
\hline $\begin{array}{l}\text { Construction (National) } \\
\text { This organization had previously focused } \\
\text { their activities on the housing marker but } \\
\text { then decided to concentrate their efforts } \\
\text { on attracting new clients such as large } \\
\text { supermarkets in order to weather the } \\
\text { downturn in the economic climate. These } \\
\text { new clients were deemed to be being } \\
\text { much more demanding to work for but } \\
\text { were viewed as an integral aspect of the } \\
\text { organization's growth strategy. }\end{array}$ & $\begin{array}{ll}\text { - } & * \text { HR Manager } \\
\text { - } & \text { Construction Site } \\
& \text { Manager } \\
\text { - } & \text { Construction } \\
& \text { Graduate (Retail } \\
& \text { Team) }\end{array}$ & Yes \\
\hline $\begin{array}{l}\text { Aerospace (Multinational) } \\
\text { This is a subsidiary of a large } \\
\text { multinational. Although this organization } \\
\text { had previously embarked on a } \\
\text { programme of redundancies, they were } \\
\text { currently experiencing a period of rapid } \\
\text { growth and expansion. The strategy for } \\
\text { growth focuses on emerging technologies } \\
\text { within the industry. }\end{array}$ & $\begin{array}{ll}- & \text { Graduate HR } \\
& \text { Manager } \\
\text { - } & \text { IT Line Manager } \\
\text { - } & \text { IT Graduate }\end{array}$ & Yes \\
\hline $\begin{array}{l}\text { IT Software Development } \\
\text { (Multinational) } \\
\text { A software development company that } \\
\text { has grown rapidly in recent years. They } \\
\text { are focused maximizing the opportunities } \\
\text { for business growth through the } \\
\text { development of more complex } \\
\text { technologies. }\end{array}$ & $\begin{array}{ll}\text { - } & \text { HR Manager } \\
\text { - } & \text { Line Manager } \\
\text { - } & \text { Graduate Trainee }\end{array}$ & Yes \\
\hline $\begin{array}{l}\text { Public Sector Healthcare (National) } \\
\text { This organization has run a graduate } \\
\text { development scheme for over } 50 \text { years. } \\
\text { At the time of the research constraints to } \\
\text { the public purse meant that have had to } \\
\text { deal with budgetary pressures. }\end{array}$ & $\begin{array}{l}\text { - } \text { *Graduate Scheme } \\
\text { Manager } \\
\text { - } \quad \text { Line Manager } \\
\text { - } \quad \text { Graduate Trainee }\end{array}$ & Yes \\
\hline $\begin{array}{l}\text { Charitable (Local Operation of } \\
\text { Worldwide Charity) }\end{array}$ & $\begin{array}{l}\text { *HR and Finance } \\
\text { Manager (Also } \\
\text { responsible for Line } \\
\text { Management) }\end{array}$ & No \\
\hline
\end{tabular}




\begin{tabular}{|l|l|l|}
\hline $\begin{array}{l}\text { This charity was experiencing significant } \\
\text { budgetary pressures. It was aiming to } \\
\text { develop a number of new charitable } \\
\text { programmes with the intention of } \\
\text { attracting more funding. }\end{array}$ & $\bullet$ & \\
\hline Hospitability (Regional) & $\bullet$ *HR Manager & No \\
$\begin{array}{l}\text { This was one of the largest hospitality } \\
\text { companies in the region. At the time of } \\
\text { the research it was experiencing a number } \\
\text { of business challenges given that the } \\
\text { hospitability industry was majorly } \\
\text { affected during the economic downturn. } \\
\text { The company has now been acquired by } \\
\text { another organization but a key feature of } \\
\text { their business strategy remains within the } \\
\text { area of customer service. }\end{array}$ & $\begin{array}{l}\text { Manager } \\
\text { Maduate Hospitality }\end{array}$ & \\
\hline
\end{tabular}


Table 3 - Findings

\begin{tabular}{|c|c|c|c|c|}
\hline Organization & $\begin{array}{c}\text { RO1 } \\
\text { How is 'graduate talent' } \\
\text { conceptualized? }\end{array}$ & \begin{tabular}{|c|}
$\mathrm{RO2}$ \\
$\begin{array}{c}\text { Understand the priorities in relation to } \\
\text { recruiting, developing and retaining } \\
\text { graduate talent to achieve } \\
\text { organizational objectives. }\end{array}$ \\
\end{tabular} & $\begin{array}{c}\text { RO3 } \\
\text { Challenges associated with recruiting, } \\
\text { developing and retaining graduates }\end{array}$ & $\begin{array}{c}\text { RO4 } \\
\text { The novel practices used to overcome } \\
\text { the challenges of the graduate talent } \\
\text { pool }\end{array}$ \\
\hline $\begin{array}{l}\text { Construction (National) } \\
\text { This organization had previously } \\
\text { focused their activities on the } \\
\text { housing marker but now } \\
\text { concentrate their efforts on } \\
\text { attracting new clients such as } \\
\text { supermarkets who were deemed to } \\
\text { be being much more demanding to } \\
\text { work for but were viewed as } \\
\text { integral to the organization's } \\
\text { growth strategy. }\end{array}$ & 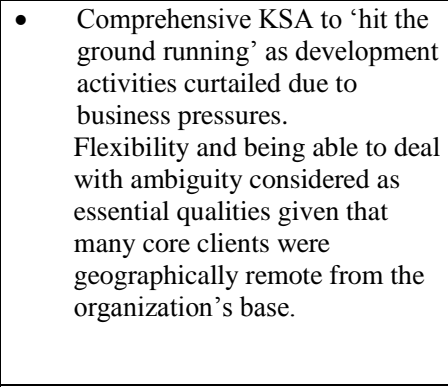 & $\begin{array}{ll}- & \text { Due to business priorities and } \\
\text { operational pressures, reduced time } \\
\text { for development activities for } \\
\text { graduates which resulted in } \\
\text { emphasis on experiential learning } \\
\text { for graduates. }\end{array}$ & $\begin{array}{l}\text { Tough and highly competitive } \\
\text { culture (internally and externally) } \\
\text { for graduates to adapt to. } \\
\text { Need for resilience and ability to } \\
\text { work with challenging targets which } \\
\text { are often imposed by clients who } \\
\text { have very tight deadlines. }\end{array}$ & 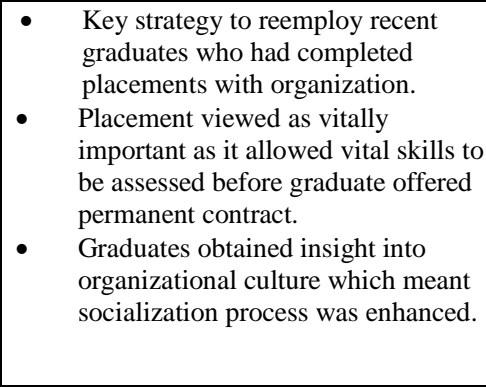 \\
\hline $\begin{array}{l}\text { Aerospace (Multinational) } \\
\text { This is a subsidiary of a large } \\
\text { multinational. Although this } \\
\text { organization had previously } \\
\text { embarked on a programme of } \\
\text { redundancies, they were currently } \\
\text { experiencing a period of rapid } \\
\text { growth and expansion. The strategy } \\
\text { for growth focuses on emerging } \\
\text { technologies within the industry. }\end{array}$ & $\begin{array}{l}\text { - } \quad \text { Graduate talent expected to } \\
\text { bring innovation and creativity } \\
\text { to organization. } \\
\text { - Graduates need to bring } \\
\text { something fresh. }\end{array}$ & $\begin{array}{l}\text { - } \text { Graduate intake for formal graduate } \\
\text { programme reviewed regularly and } \\
\text { linked to overall strategy and } \\
\text { designed to ensure there was } \\
\text { flexibility in terms of KSA } \\
\text { workforce. } \\
\text { - } \begin{array}{l}\text { Priorities placed on recruiting for } \\
\text { more advanced and senior level } \\
\text { positions }\end{array}\end{array}$ & 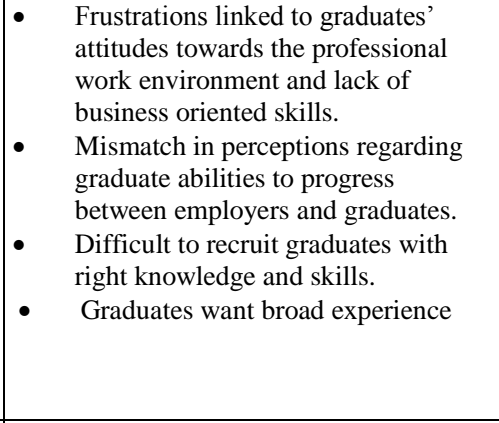 & $\begin{array}{l}\text { Development changed from } \\
\text { functional to generalist development } \\
\text { programme to ensure that graduates } \\
\text { receive greater exposure to varied } \\
\text { parts of the business. } \\
\text { Stronger links fostered with local } \\
\text { and national universities to help } \\
\text { shape development of university } \\
\text { programmes to ensure that graduates } \\
\text { are equipped with more specific skill } \\
\text { sets. } \\
\text { Mentoring scheme for placement } \\
\text { students and recent graduates. }\end{array}$ \\
\hline $\begin{array}{l}\text { IT Software Development } \\
\text { (Multinational) } \\
\text { A software development company } \\
\text { that has grown rapidly in recent } \\
\text { years. They are focused on } \\
\text { maximizing the opportunities for } \\
\text { business growth through the } \\
\text { development of more complex } \\
\text { technologies. }\end{array}$ & 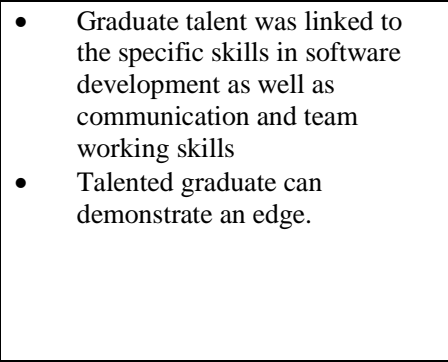 & $\begin{array}{l}\text { Graduates seen as an essential part } \\
\text { of TM strategy but issues noted } \\
\text { regarding the actual skills that } \\
\text { available graduates possessed. } \\
\text { - Need for very specific skills that } \\
\text { allowed the IT Company to compete } \\
\text { for new business meant that } \\
\text { recruiting more recent graduates was } \\
\text { in some cases secondary to obtaining } \\
\text { employees who could contribute } \\
\text { very quickly. }\end{array}$ & $\begin{array}{l}\text { Skills shortages meant the market } \\
\text { for the most skilled and talented } \\
\text { graduates was extremely } \\
\text { competitive. } \\
\text { Very skilled graduates in a strong } \\
\text { bargaining position, especially in the } \\
\text { local labour market. } \\
\text { Lack of loyalty perceived to be a } \\
\text { problem as recent graduates often } \\
\text { prepared to move for new } \\
\text { opportunities. }\end{array}$ & $\begin{array}{l}\text { - IT organization sought to accentuate } \\
\text { the possibility of longer-term career } \\
\text { development in this organization if } \\
\text { they possessed appropriate skills. } \\
\text { Coaching also formalized and } \\
\text { graduates given opportunities to } \\
\text { move around in organization taking } \\
\text { on overseas assignments etc. } \\
\text { Online induction tools used to } \\
\text { upskill graduates before they begin } \\
\text { work. }\end{array}$ \\
\hline
\end{tabular}




\begin{tabular}{|c|c|c|c|c|}
\hline $\begin{array}{l}\text { Public Sector Healthcare } \\
\text { (National) } \\
\text { This organization has run a } \\
\text { graduate development scheme for } \\
\text { over } 50 \text { years. At the time of the } \\
\text { research constraints to the public } \\
\text { purse meant that have had to deal } \\
\text { with budgetary pressures. }\end{array}$ & $\begin{array}{l}\text { Graduates who could contribute } \\
\text { something special key to this } \\
\text { organization. } \\
\text { Fresh creative and innovative } \\
\text { approach to role and } \\
\text { organizational activities seen as } \\
\text { key. }\end{array}$ & $\begin{array}{l}\text { Graduates who could illustrate their } \\
\text { drive, motivation to learn and who } \\
\text { are flexible in terms of taking } \\
\text { opportunities particularly valued. } \\
\text { Given specialist nature of the } \\
\text { organization (developing support } \\
\text { and management development } \\
\text { programmes for Healthcare sector) } \\
\text { the organization acknowledged that } \\
\text { further development was essential } \\
\text { for graduates. }\end{array}$ & $\begin{array}{l}\text { Difficulties in public sector } \\
\text { environment led to pressures, but the } \\
\text { long established graduate } \\
\text { programme meant that the } \\
\text { organization would continue to seek } \\
\text { very highly motivated recent } \\
\text { graduates. }\end{array}$ & $\begin{array}{l}\text { - Keeping the formalized structure of } \\
\text { the graduate programme was } \\
\text { important. } \\
\text { Generalized nature of programme } \\
\text { was valued by graduates who } \\
\text { realized that a secure and well paid } \\
\text { position could accrue at the end of } \\
\text { the process. }\end{array}$ \\
\hline $\begin{array}{l}\text { Charitable (Local Operation of } \\
\text { Worldwide Charity) } \\
\\
\text { This charity was experiencing } \\
\text { significant budgetary pressures. It } \\
\text { was aiming to develop a number of } \\
\text { new charitable programmes with } \\
\text { the intention of attracting more } \\
\text { funding. }\end{array}$ & $\begin{array}{l}\text { - } \\
\text { Experience and ability to make } \\
\text { an impact within the } \\
\text { organization. } \\
\text { - }\end{array}$ & $\begin{array}{ll}- & \text { Priority placed upon experienced } \\
\text { employees as opposed to graduates } \\
\text { - } & \text { Lack of resources for developing } \\
\text { graduates } \\
\text { Third level education not considered } \\
\text { essential - linked to risk of } \\
\text { excluding potential talent }\end{array}$ & $\begin{array}{l}\text { Graduate applicants lacking in } \\
\text { necessary skills and competencies to } \\
\text { deal with organizational challenges. } \\
\text { Retention noted as a problem - } \\
\text { acknowledgement that organization } \\
\text { could not offer extensive } \\
\text { development opportunities expected } \\
\text { by recent graduates. }\end{array}$ & $\begin{array}{l}\text { Graduates encouraged to join } \\
\text { organisation as volunteers which } \\
\text { helped to fill human resource gaps } \\
\text { Graduates volunteers have } \\
\text { opportunity to upskill whilst } \\
\text { organization can 'road test' } \\
\text { graduates for potential job } \\
\text { opportunities. }\end{array}$ \\
\hline $\begin{array}{l}\text { Hospitability (Regional Northern } \\
\text { Ireland) } \\
\text { This was one of the largest } \\
\text { hospitality companies in the region. } \\
\text { At the time of the research it was } \\
\text { experiencing a number of business } \\
\text { challenges given the fallout from } \\
\text { the economic downturn. The } \\
\text { company has now been acquired by } \\
\text { another organization but a key } \\
\text { feature of their business strategy } \\
\text { remains focused on customer } \\
\text { service. }\end{array}$ & $\begin{array}{ll}- & \text { Graduates should offer } \\
\text { something different and extra. } \\
\text { Perception that graduates should } \\
\text { be able to adopt quickly to } \\
\text { behavioural and technical } \\
\text { competency requirements in a } \\
\text { changing hospitality sector. }\end{array}$ & 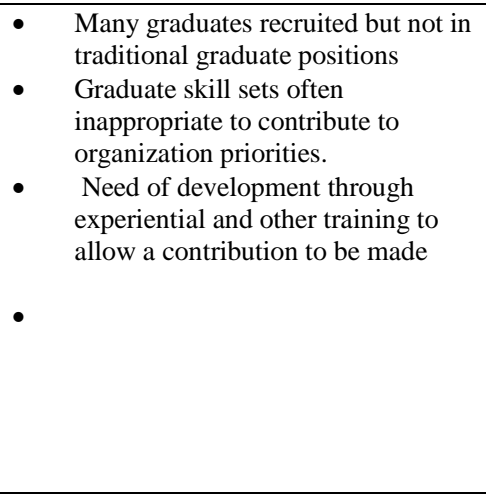 & 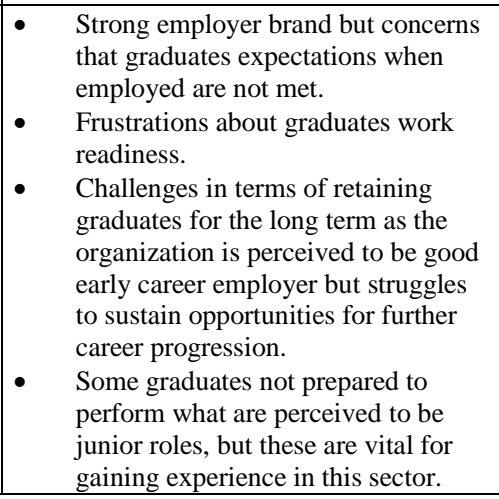 & $\begin{array}{l}\text { Employer brand seen as an } \\
\text { important element of attracting } \\
\text { graduates to the organization. } \\
\text { Key focus for TM strategy is to } \\
\text { open opportunities for accelerated } \\
\text { progression to 'under employed' } \\
\text { graduates when they demonstrate } \\
\text { desired skills and attitude. } \\
\end{array}$ \\
\hline
\end{tabular}


